\title{
Transformativ forskningsmetode - belyst gennem et projekt om mødefacilitering
}

\author{
Ib Ravn
}

Mange forskere ønsker givetvis, at deres forskning kan bidrage til arbejdslivets eller organisationers udvikling. Men der findes ikke mange metoder, der tillader os at gøre det gennem selve forskningsprocessen. I et nyligt gennemført forsknings- og udviklingsprojekt om bedre møder benyttede vi en såkaldt transformativ metode, der netop tilstræber forbedring af praksis gennem forskningsindsatsen. Metodens faser er de klassiske, men med en pragmatisk-normativ drejning: Vi starter med en teori om, hvordan et praksisfelt kunne se ud, hvis det fungerede meget bedre end nu (in casu: en teori om bedre møder). Derudfra afleder vi konkrete, handlingsanvisende hypoteser, som vi tester $i$ et eksperiment $i$ samarbejde med feltets praktikere. Vi evaluerer på sædvanlig vis, modificerer teorien og bliver klogere på, hvordan det skal gøres bedre næste gang.

\section{Fra beskrivelse, forklaring og kritik - til forbedring}

$\mathrm{H}$ vad laver en forsker inden for arbejdslivsforskning - eller mere generelt, en samfundsforsker? Vi går ikke galt i byen ved at hævde, at hun beflitter sig på at beskrive, forklare og kritisere de fænomener, der optræder på hendes interesseområde. Beskrivelse fortæller os, hvordan virkeligheden fremtræder; forklaring er forsøget på at finde og forstå sammenhænge; og kritik er samfundsforskningens særlige bidrag, fremherskende efter de venstreradikale 1970'ere: ønsket om at afsløre magtrelationer og destabilisere det socialt vante og fastlåste.

Til disse tre lægger der sig en fjerde bestræbelse, der ofte har spillet med i samfundsforskningen, men som regel i en underdrejet og slet integreret rolle: Ønsket om at bidrage til at forandre og forbedre samfundets institutioner og menneskers handlingsmuligheder og dét mere direkte og konstruktivt end gennem kritik.

Dette ønske synes ikke mindst fremtrædende $\mathrm{i}$ arbejdslivsforskningen, hvis genstand, arbejdslivet, så ubesværet tænkes normativt, f.eks. i den hyppigt forekommende vending 'det gode arbejdsliv' (der trækker næsten dobbelt så mange Googlehits som 'det gode samfund'). Hvilken arbejdslivsforsker ønsker sig ikke, at hendes forskning på lang sigt vil bidrage til at skabe et bedre arbejdsliv for denne eller hin gruppe medarbejdere eller for mennesker på arbejdspladser generelt?

Arbejdslivsforskere har det i denne henseende en anelse lettere end mange andre samfundsforskere, bl.a. fordi den udmærkede metode interventionsstudiet (Kristensen 2005) står til deres rådighed. Her starter forskningen ud fra en normativ forestilling om, at intervention $X$ vil bidrage til at skabe en bedre tilstand $\mathrm{Y}$ på praksisfeltet. 
En sådan normativ tænkning fungerer pga. denne forsknings udspring $\mathrm{i}$ arbejdsmiljøforskning, arbejdsmedicin og sundhedsforskning, idet 'sundhed' som værdi eller ideal ikke er specielt kontroversielt eller politisk at arbejde for rent forskningsmæssigt.

Vanskeligere bliver det, hvis vi træder ud af arbejdsmiljøforskningen og spørger til f.eks. beskæftigelsespolitik, ledelsesteknologier eller medarbejderdemokrati. Her strides politiske værdier mere indlysende; der er ingen let opnåelig enighed om, hvad en intervention skal fremme, og forskeren vil lettere blive anklaget af journalister, politikere og bordherrer for at politisere.

Trods disse vanskeligheder er der flere skoler i samfunds- og organisationsforskningen, der søger at skabe alternativer til det bestående. Ud over interventionsforskning (se også Rothman \& Thomas 1994) er det bl.a. aktionsforskning (Reason \& Bradbury 2001), design-based research (Cobb m.fl. 2003) og organizational design science (van Aken 2005; Jelinek m.fl. 2008). Mit ærinde i denne korte artikel er ikke at gennemgå disse fornuftige tilgange. Jeg vil $i$ stedet, med udgangspunkt $i$ et projekt om bedre møder som kolleger og jeg er ved at afslutte, beskrive nogle trin i en forskningscyklus, hvormed man qua forsker kan bidrage til udvikling af social og organisatorisk praksis. Metoden har store fællestræk med interventionsstudier og forskeres evaluering af andres forandringsprojekter, men den rolle, som teori og hypotesetestning spiller i projektet, gør det til eksempel på en forskningsmetode, som jeg, lidt ambitiøst måske, kalder transformativ, dvs. omformende. En sådan metode sætter altså forskere i stand til, som forskere, at bidrage aktivt til en omformning af menneskers handlingsmåder og sociale institutioner - og ikke nøjes med kritisk at påpege behovet herfor.

I det følgende nikker jeg kort til mine inspirationskilder for denne type forskning og præsenterer derefter det nævnte eksempel herpå, vores projekt om forbedring af mødekulturen på danske arbejdspladser. Dette eksempel bruger jeg derpå til at fremhæve de nævnte trin i en transformativ forskningscyklus. Jeg lægger særlig vægt på vores opfattelse af teori som ikke blot nutidsbeskrivende men fremtidsrettet, ikke blot eksplanatorisk eller kritisk, men normativ og transformativ. Jeg runder af med nogle betragtninger om begrænsninger og udfordringer ved denne type forskning.

\section{Inspirationskilder}

Som det fremgår, er sondringen mellem facts og værdier central. Videnskaben handler jo om facts, ikke værdier, mener vi. I filosofihistorien ses sondringen ofte som et svælg; det kaldes Humes lov, efter hvilken man ikke kan slutte fra et 'er' til et 'bør' (Hume 1741/1986, 521). Svælget blev af filosoffen G.E. Moore (1903, kap. 1) formuleret som den 'naturalistiske fejlslutning' og herefter knæsat i nyere samfundsforskning som forestillingen om, at vi ikke kan udlede anbefalinger til social praksis af vores forskning i social praksis. Selv om argumentationen bag denne forestilling er blevet så rigeligt tilbagevist (se Blegvad 1959; Searle 1964, Brinkmann 2009), ligger den stadig dybt i mange forskere.

Mange andre forskere har dog ikke fundet nogen afgrund mellem fakticitet og normativitet og har søgt at bedrive humanog samfundsforskning på en måde, der direkte søger at tilgodese menneskers behov for liv og udfoldelse. Lad mig her nævne tre personlige inspirationskilder til en sådan tænkning. De orienterer sig alle mod samfundsmæssig udvikling og menneskers fremtid, og de inviterer derfor samfundsforskningen til at beskæftige sig lige så meget med den virkelighed, mennesker ønsker sig, som den, de har. 
Forfatter og arkitekt Poul Bjerre har fremlagt en humanistisk samfunds- og videnskabsteori (Bjerre 1972; 1988), der sætter dækningen af menneskers behov øverst på forskningens dagsorden. Ligesom et hus kan tegnes, så det enten bliver et børnefjendsk pralehus eller understøtter børnenes (og de voksnes) behov, kan også en by og et helt samfund indrettes til hæmning eller fremme af menneskers behov. Bjerre mente, at en eksperimentel samfundsforskning skulle efterligne den lægevidenskab, der endnu i hans tidlige år (1950'erne) var et uplettet, humanistisk forbillede for mange. En sådan samfundsforskning skulle eliminere de mest fortrædvoldende organisationsformer, så vi i videnskabens karakteristiske langsomme og grundige tempo kunne nærme os de idealer om demokrati, retfærdighed, frihed og lige muligheder, der svarer til lægevidenskabens aldrig opnåelige, men altid approksimérbare ideal om sundhed.

Bjerre er ikke specielt kendt af danske samfundsforskere, men hans humanistiske tænkning genfindes hos hans ven og åndsfælle Villy Sørensen, der sammen med sine medforfattere i Oprør fra Midten (Meyer m.fl. 1978) gav en praktisk og positiv formulering af en sådan bedre fremtid for Danmark som helhed: det humane ligevægtssamfund.

En lige så humanistisk tilgang finder vi hos den amerikanske organisationsforsker og systemtænker Russell L. Ackoff (1994). På inspiration fra sin lærer Edgar Singer, elev af pragmatismens grundlægger William James, insisterede Ackoff på den videnskabelige metodes relevans for praktiske problemer i virksomheder og samfund. Han skabte i 1970'erne en helhedsorienteret planlægningsmetode, 'interaktiv planlægning', der involverer alle et systems aktører og interessenter i en ambitiøs formulering af et idealiseret design af deres system (Ackoff, 1981). "Jeres organisation broendte ned $i$ nat", sagde han på store fællesmøder i de organisationer, han fungerede som rådgiver for. "Design nu det bedste system, der kan udføre jeres mission!". Kun tre kriterier skulle det opfylde: Det skal være teknologisk realistisk (ingen ukendt teknologi), operationelt muligt (det skal kunne fungere nu) og det skal være et lærende system, der hele tiden kan blive bedre (altså ingen utopier).

Ud fra det idealiserede design afleder grupper af medarbejdere, ledere og organisationens andre interessenter først langsigtede og derpå kortsigtede mål, så man kan gå gang med det samme, idet man styrer efter det idealiserede design. Uenigheder mellem interessenter afklares så vidt muligt med eksperimentet: "Lad os se, hvis løsning viser sig at fungere bedst" - bedst i betydningen: fører os længst i retning af det idealiserede design. I Ackoffs arbejder finder vi en særlig amerikansk kombination af eksperimentel videnskabelighed, pragmatisk problemløsning, participativ planlægningsmetode og humanistisk fremtidsorientering, der synes relevant for enhver udviklingsorienteret samfundsforskning.

En tredje inspirationskilde er en intellektuel retning, der tilsvarende fokuserer på menneskers evne til at skabe deres liv og samfund i en åben verden: socialkonstruktionismen. Velkendte er bidragene fra Berger \& Luckmann (1966), Gergen (1982) og Weick (1995), der i de seneste 10-15 år har bredt sig som en steppebrand i en række danske universitetsmiljøer. Socialkonstruktionismens påpegning af alle mentale og sociale institutioners menneskeskabte karakter udgør et passende bagtæppe (Ravn 1985) for Ackoffs mere assertive fremhævelse af, at vi ikke kan nøjes med vores institutioner, som de er; vi må forsøge at skabe os den radikalt anderledes og bedre fremtid, vi ønsker.

Lad mig sammenfatte disse tre inspirationer fra Bjerre, Ackoff og socialkonstruktionismen i en simpel erkendelse: Sociale 
institutioner konstrueres løbende af mennesker; de er ikke statiske genstande, der kan beskrives positivistisk og værdifrit. Om vi vil det eller ej, påvirker human- og samfundsforskere gennem deres forskning disse konstruktionsprocesser. Hvorfor da ikke sætte som eksplicit mål for vores forskning, at vi skal bistå med at få de sociale konstruktioner til at fungere så tilfredsstillende som muligt for de involverede mennesker? Det vil sige at bidrage til at skabe et stadigt bedre liv for stadigt flere mennesker $i$ et stadigt mere retfærdigt samfund. Dette mål turde ikke være specielt kontroversielt; vanskeligheden ligger $i$ at finde en metode, hvormed det kan gøres, samtidig med at vi tackler det meget vanskelige værdispørgsmål: Hvem afgør, hvad der er 'bedre'?

Jeg har i tidligere publikationer beskrevet en sådan metode abstrakt (Ravn 1991; Baburoglu \& Ravn 1992). Lad os her se, hvordan det kan gøres konkret.

\section{Møder der skaber værdi og mening}

Som konsulent i rådgivningsfirmaerne Amphion og Nellemann Konsulenterne arbejdede jeg med facilitering og videndeling, og ved min ansættelse på Learning Lab Denmark i 2002 formulerede jeg 'Facilitering af videnprocesser' som mit forsknings- og udviklingsfelt, herunder videndelingsmøder. Sammen med mine kolleger Nina Tange og Joan Rokkjær tog jeg kontakt til en række private virksomheder og offentlige institutioner og fandt hurtigt ud af, at det ikke så meget var videndeling, der var interesse for, som det mere elementære spørgsmål: Hvordan afholder man overhovedet et godt møde? - om så formålet med mødet er videndeling eller noget andet.

Mødeledelse har man i 30-40 år kunnet tage kurser i og hyre konsulenter til, ligesom der findes en omfangsrig litteratur med gode råd til møder - specielt den type møder vi sætter fokus på her: Møder på arbejdspladsen, møder i organisationer (idet vi holder andre møder uden for: politiske møder, borgermøder, konferencer, møder i civilsamfundet og foreningslivet, osv.). Egentlig forskning i professionel mødekultur eller bedre møder i organisationer findes der imidlertid meget lidt af (se dog Schwartzman 1986, Romano \& Nunamaker 2001).

Ved nærmere eftersyn syntes hele praksisfeltet ikke at have udviklet sig synderligt i de nævnte 30-40 år. Det er stort set de samme principper, håndbøgerne lægger vægt på, og det er de sædvanlige teknikker, som mødeledere bliver uddannet i: sammensæt en dagsorden, send den ud i god tid, vedlæg materialer, indkald de rigtige, vælg referent, styr tiden stramt, hold en talerliste, træf beslutninger, skriv referat, send det ud hurtigt efter og indkald til næste møde.

Selv om enhver leder kender denne rutine, klarer mange mødeledere sig tilsyneladende tit uden. I stedet improviserer man sig gennem mødet uden dagsorden eller noget særligt klart diskussionsfokus. Dette problem og de mange andre, som vi selv havde erfaret på møder, og som blev rapporteret til os anekdotisk, kunne vi glimrende have udarbejdet et klassisk forskningsprojekt om. Vi kunne rekruttere fem arbejdspladser, iagttage 100 møder, interviewe 25 mødeledere og 25 mødedeltagere og udsende et spørgeskema til 1000 flere. Halvandet år senere kunne vi have produceret en omfattende beskrivelse af små og store møder på arbejdspladser, signalement af den aktuelle danske mødekultur, identifikation af mødetyper og de hyppigste problemer på møder med påpegning af mødetabuer og kritik af underliggende magtrelationer; det hele sammenskrevet $\mathrm{i}$ en længere forskningsrapport, der i sidste kapitel kunne indeholde en række anbefalinger til bedre møder. 
Men hvor interessant ville det være? Ville nogen synes, det var væsentligt nok til, at de ville betale en million eller tre for det? Ville det være to års arbejde værd? Det mente vi ikke. Det måtte være muligt at bidrage mere direkte til en nyt $\mathrm{og}$ forhåbentlig bedre praksis, samtidig med at vi leverede en forskningsindsats. Vi fandt, at hele feltet led under mangel på både nytænkning og ny praksis. Møder er ofte kedsommelige at gå til, og feltet er intellektuelt set decideret usexet. Her lå en udfordring: At forstå og fortolke mødefænomenet på en ny og inspirerende måde, der viser andre veje i håndtering og afvikling af møder og konkret hjælper feltets praktikere med at holde væsentligt bedre møder.

Sådan en forståelse og fortolkning dannede vi under et længere forarbejde, bl.a. gennem et pilotprojekt med fem større virksomheder inden for bioteknologi, finans og energi (Ravn 2007). Vi erfarede, at møder ofte forstås som rutine, en lidt træls proces, der kværner langsomt gennem en dagsorden eller kører rundt i emnerne på må og få. Vi valgte som alternativ at anlægge et skabende perspektiv, der betoner tre forhold:

1. Det skabende. Møder ser vi ikke som et sted, hvor en organisation vedligeholdes, og dens rutiner reproduceres. Vi anskuer det i stedet som et forum for skabelsen af nye betydninger (Weick 1995) og ændring af virkeligheder gennem fortolkning (Gergen 1982), forhandling og ofte konflikt (Friedman \& Antal 2005).

2. Værdi. Som alt andet er møder en del af en global, social virkelighed. Lad os anlægge det syn, at mennesker på arbejdspladser går til møder for at fremme sagers udvikling, dvs. for at skabe værdi for organisationens kunder og brugere. 'Værdiskabelse' forstås i erhvervslivet oftest som det, Ghoshal m.fl. (1999) kalder 'value appropriation', dvs. værdikapring.
Et mere samfundsansvarligt stakeholderperspektiv (Donaldson \& Preston 1995) vil betone værdiskabelse som en ydelse til organisationens interessenter, hvor organisationen leverer et bidrag til samfundets kvalitative udvikling og borgernes livskvalitet (Ackoff 1994).

3. Mening. Kværnende, kedelige møder opleves typisk som meningsløse. Men møder kan også skabe mening for deltagerne, når de kommer til orde, får indflydelse, bruger deres kompetencer og sætter hver deres særlige præg på det fælles arbejde. En bred litteratur om medarbejderindflydelse og selvbestemmelse ( $\mathrm{fx}$ Deci m.fl. 1989) og mening i arbejdslivet (Isaksen 2000; Ravn 2008) understøtter dette perspektiv på arbejdslivet i almindelighed.

Sådan kunne møder være: Man kan på møder skabe nye virkeligheder, der producerer voerdi for mødets eksterne interessenter og mening for deltagerne. Fra at se og udtrykke denne mulighed, dette potentiale for møder, er der kun et kort skridt til at udnævne det som mål og ideal, en første formulering af et idealiseret design, som vi qua forskere vil bistå mødeansvarlige med at søge at realisere. Heraf titlen på vores projekt, de tre kernebegreber, der udtrykker det gode møde: 'Møder der skaber værdi og mening' (som projekttitel forkortet MSVM). Man kan opfatte denne forståelse af møders potentiale som en teori for bedre møder, og oven i købet en videnskabelig teori.

\section{Et eksperiment med facilitering af møder}

Hvis projekt MSVM ikke blot skulle være et skrivebordsprojekt, måtte vi forankre det meget abstrakte 'idealiserede design' i konkret dansk mødevirkelighed. Hvordan ser dén ud? Sonderinger i dansk mødekultur, som den har udfoldet sig gennem de 
sidste 50 år, viste os, at der groft sagt har været to faser: frem til 1970'erne dominerer det autoritære møde, hvor en leder fører ordet og involverer deltagerne minimalt. Fra 1970'erne breder ungdomsoprørets antiautoritære møder sig ganske langsomt ud på arbejdspladserne, først ud i de pædagogiske og sociale institutioner, men fra 1990'erne også til mange andre offentlige og private virksomheder. Det giver den nu velkendte egalitære, kollektivistiske og inkluderende mødekultur, hvor alle kan få ordet og beholde det så længe, de vil - de lange og resultatsvage snakkemøder. Mellemformer er meget almindelige, med en leder, der fylder (for) meget, indtil medarbejderne så får lov til at snakke (for længe).

Hinsides disse to ekstremer, det autoritære og det egalitære møde, kan man imidlertid ane en tredje mulighed, der forener det bedste af de to ekstremer. Det bedste identificerer vi dels som det stramme og resultatfokuserede fra den autoritære mødeledelse og dels det åbne og involverende fra den egalitære mødestil.

En sådan tredje vej kan fremmes ved hjælp af facilitering (Hogan 2003). Facilitering er den blide og venlige styring af et mødes form, fokus og energi, så den mødeansvarliges og deltagernes mål nås. Lederen kan være facilitator, men en kollega blandt mødedeltagerne kan også udpeges. Facilitator har ansvaret for at styre deltagerne mod målet og det på en måde, som de accepterer - ellers udpeges en ny facilitator næste gang.

Vi slipper ikke uden om magtspørgsmålet, og i en traditionelt ledet organisation vil en facilitator have vanskeligt ved at være i afgørende modstrid med sin leder. En kompetent og modig facilitator vil imidlertid på mødedeltagernes vegne udfordre den forståelse, som ledelsen eller andre traditionelle magthavere repræsenterer. Denne demokratiske eller participative funktion er et vigtigt element i faciliteringens kunst: gennem involverende teknikker at give stemme til de mødedeltagere, der normalt ikke bruger den eller har nogen. Med facilitering kan man således i mange tilfælde kunne skabe både værdi for mødets eksterne interessenter (kunder, borgere, brugere) og mening for deltagerne. Det var i hvert fald vores personlige erfaring fra facilitering i konsulent- og arbejdssammenhænge, og den forventning ønskede vi at afprøve mere systematisk i et eksperiment.

Et sådant eksperiment skulle teste et par hypoteser. I pilotprojektet havde vi erfaret, at mellemledere i større danske virksomheder faktisk er udmærkede til mødeledelse i klassisk aftapning - i hvert fald, når de blev observeret af os. Mange ledere kender og kan bruge de sædvanlige metoder: dagsorden, indkaldelse, tidsstyring, talerstyring, beslutningstagning, referering osv. Men de mere subtile aspekter af en moderne ledelses- og samarbejdskultur var de ikke gode til at integrere i mødet: Det at lytte til sine medarbejdere og anerkende dem, at involvere dem, hjælpe dem med at bruge deres kompetencer og ressourcer i mødet, skabe visioner og begejstring, skabe sammenhold og fællesskab om mødets resultater, være konstruktiv og gribe muligheder frem for at fokusere på problemer, løse småkonflikter gennem mægling og være sammen om at skabe værdi og behovstilfredsstillelse for organisations kunder og bruger.

Alle disse elementer i moderne ledelse var lederne ikke ret gode til at føre ind i deres møder, observerede vi (Ravn 2007) formentlig fordi det klassiske mødes værktøjskasse blev dannet for 30-40 år siden. Facilitering er en mere tidssvarende mødestyringstilgang, der allerede inkorporerer en del af disse elementer (Hogan 2003) og konceptuelt kan rumme resten.

Vores første hypotese, uformelt formuleret, var da: Danske mødeledere kan udføre klassisk mødeledelse, men de kender ikke el- 
ler er ikke gode til facilitering (udtrykt kort: $\mathrm{Mø}+, \mathrm{Fa} \div$ ). Endnu en deskriptiv hypotese antydede jeg ovenfor: Møder på danske arbejdspladser skaber hverken meget mening for deltagerne eller værdi for kunderne (MeVæ $\div)$. Hermed har vi lagt op til den sidste og centrale hypotese, der udtrykker det forandrende eller transformative element: Ved at gå over til at facilitere ens møder, i stedet for blot at lede dem på klassisk vis, kan man skabe mere mening for deltagerne og værdi for kunderne (Fa $\uparrow \Rightarrow \mathrm{Me} \uparrow, \mathrm{V} \uparrow$ ).

Til at teste disse hypoteser i et realistisk eksperiment rekrutterede vi tre meget forskellige virksomheder: en mindre bank, en stor kommunalforvaltning og et mellemstort ministerium. Hver blev inviteret til at sende 30-50 mellemledere på et udviklingsforløb i mødefacilitering, bestående af fælles heldagsworkshops, individuel coaching og redesign af udvalgte mødetyper i hver virksomhed. Dette uddannelsesforløb blev tilrettelagt i samarbejde med hver enkelt virksomhed og blev gennemført af os personligt som undervisere og coaches (hvilket udgør en klassisk kilde til validitetsproblemer; mere herom nedenfor).

Til testning af hypoteserne gennemførte vi en før- og eftermåling bestående af interviews med mødeledere og mødedeltagere (ca. 40 før og 40 efter), observation af møder (ca. 20 før og 20 efter), samt et 29 -item survey af alle de medarbejdere, der går til møder hos de uddannede mødeledere og således er godt placeret til at vurdere mødernes kvalitet ( $\mathrm{n}=\mathrm{ca} .800$, data er under bearbejdning).

Indhold af interviewguide, observationsguide og spørgeskema blev udledt fra teoriens fire elementer: Mødeledelse, Facilitering, Værdiskabelse og Meningsskabelse. For eksempel er det en vigtig ting i klassisk mødeledelse, at der foreligger en dagsorden ved mødestart. Det omsatte vi til et af seks items i faktor 'Mødeledelse': "I hvor høj grad står det ved et typisk mødes indledning klart, hvad I skal tale om?" Det er derimod ikke en del af klassisk mødeledelse, at deltagerne på forhånd ved, hvad de skal udrette gennem den snak, for det fremgår af den klassiske dagsordenen - der står blot 'Drøftelse af direktions udspil $X^{\prime}$, for eksempel. Det er en facilitator derimod meget opmærksom på, for han skal sikre at deltagerne udretter det, de gerne vil med mødet. Derfor indgår denne pointe som et item ud af seks i faktor 'Facilitering': "I hvor høj grad står det ved mødets indledning klart, hvad I skal udrette på mødet - ud over blot at tale om nogle ting?"

En foreløbig analyse af resultaterne af førmålingen viser, at der scores højere på første end på andet spørgsmål, dvs. der udarbejdes i rimeligt omfang dagsorden til møderne; men hvad drøftelsen af den skal føre til er mere uklart. Dette tolker vi som et lille bidrag til bekræftelse af hypotese 1 : ledere kan godt klassisk mødeledelse, og til bekræftelse af hypotese 2: møder skaber ikke stor værdi - møderne er ikke skarpt nok lagt an til at skabe resultater. (Efter at have konstateret dette i førmålingen, øvede vi i træningsforløbet den målrettede mødestart og lod deltagerne benytte en dagsordensskabelon, der aktivt formulerer, hvad der skal udrettes med hvert mødepunkt.)

Er læseren nysgerrig på de øvrige resultater, må jeg henvise til senere publikationer. Foreløbige indtryk fra data tyder på, at noget bliver bedre: de implicerede mødeledere lærer et vist mål af facilitering herunder en del konkrete teknikker til deltagerinvolvering. Så vidt vi kan se, forbedrer det meningsskabelsen, men om det er lykkedes mødelederne at få rykket ved værdiskabelsen er endnu uklart.

\section{Intervention og forskning}

Lad os se på, hvordan dette projekt om mødefacilitering kan eksemplificere den nævnte type metode, transformativ forskning. 
Videnskabsteoretisk befinder vi os indlysende i pragmatisk farvand. Videnskabelig viden skal ikke forstås som nøjagtige repræsentationer af en ekstern, objektiv virkelighed; viden er noget, der skabes gennem en involveret undersøgelse af virkeligheden (Dewey 1929), og forskning og viden fuldbyrdes i menneskers handlinger og deres konsekvenser (James 1907; Gimmler 2003).

Humanistisk taler vi også: Forskning skal tjene mennesket og dets behov (Maslow 1959; Bjerre 1972; Sørensen 1973) og ikke abstrakte kriterier om sandhed. Interessen for borgernes livskvalitet og samfundets udvikling skal ikke spille andenviolin i forhold til forskerens trang til meritering.

Et delvist slægtskab med aktionsforskning er også klart: Som forskere skal vi engagere os med et praksisfelt og bidrage til at udvikle det sammen med praktikerne (Reason \& Bradbury 2001). Jeg siger 'delvist,' fordi vores tilgang var mere ekspertbaseret end aktionsforskeres normalt mere egalitære og involverende stil - vi kom bl.a. anstigende med en næsten færdig teori og underviste praktikerne i teknikker (facilitering), de ikke eksplicit havde efterlyst.

Et andet oplagt slægtskab er med klassisk videnskabelig metode; jeg har nævnt teori, hypoteser, testning og eksperiment, alt sammen tankegods fra den hypotetiskdeduktive metode (Richards 1981, 196). Lad os se på faserne i vores projekt ved at sammenligne med den. Som bekendt starter den hypotetisk-deduktive metode med (1) et problemfelt, som man danner sig (2) en intuitiv forestilling eller ligefrem en teoretisk forståelse af. Ud fra denne teori formulerer man (3) nogle hypoteser, som (4) konfronteres med empiri, evt. i et eksperiment. Man kan da ved hjælp af (5) en måling konstatere om hypotesen holdt vand, så man evt. (6) kan revidere sin teori og (7) formulere generaliseringer til brug for videre forskning. Jeg vil kalde denne metode den klassiske, selv om den opstod som alternativ til den endnu ældre induktive metode - og på trods af, at den kun bruges i hist og pist i samfundsvidenskaberne.

I projekt MSVM gik vi gennem faser, der ligner dem i den hypotetisk deduktive metode. Men der er også radikale forskelle.

\section{Problem: En praksisfelt, der fungerer dårligt}

Almindeligvis begynder forskning med et problem, vi ikke forstå og derfor ønsker at belyse gennem forskning. I MSVM var det også en motivation: Møder på arbejdspladser er forskningsmæssigt underbelyste. Men det langt større og mere interessante problem var praktisk: Rigtig mange steder er mødekulturen nødlidende, så hvad kan man gøre for at skabe bedre møder? Taler vi rent videnskabsteoretisk i pragmatiske og humanistiske termer, er den formulering indlysende: Som forskere er det ikke nok, at vi undersøger, hvorfor møder er dårlige. Vi må også hjælpe mødeledere og mødedeltagere udvikle deres handlinger og skabe bedre møder.

Den udfordring kan tackles på mange måder. Inspirationen fra Ackoffs idealiserede designs inviterede os til at formulere et billede på, hvordan praksisfeltet ville se ud, hvis det fungerede rigtig godt. Med andre ord, hvad kendetegner gode møder?

\section{Teori - om en bedre tingenes tilstand}

I forhold til den klassiske forklarende teori tager f.eks. kritisk teori et skridt videre bort fra det bestående. Den sætter fokus på aktuel magt og undertrykkelse og baner derved vejen for, at praktikere kan danne deres egne alternativer.

Men lad os tænke forskerne ind også. Og lad os tage et skridt længere ind i en alternativ fremtid og foreslå, at samfundsviden- 
skabelig teori ikke behøver at forholde sig så tæt til den aktuelle virkelighed som klassisk antaget. Lad os forestille os en type teori, der rummer billeder på en ønskværdig, fremtidig tilstand for mennesker og sociale institutioner, sådan at man kunne sige: "Jeg har en teori om, hvordan møder kunne voere, hvis de fungerede ualmindeligt godt". Som vi så ovenfor var den teori i MSVM, kort udtrykt, at møder, der faciliteres, kan skabe stor mening for deltagerne og stor værdi for mødets eksterne interessenter. Det var vores vision - eller teori - om det gode møde.

'Vision' - fint nok, men hvorfor kalde det en videnskabelig teori? Fordi tiden, videnskabsteoretisk set, er moden til det, ja ligefrem overmoden. Inden for human- og samfundsvidenskaberne er vi for længst kommet videre end den simple realisme, der dominerede 1800-talles fysik og satte spor i den physique sociale, som Auguste Comte søgte at skabe og senere gav navnet sociologie. Et samfund rummede objektive sociale kendsgerninger (Durkheim), som man kunne ordne i lovmæssigheder, dvs. opstille teorier om. Samfundet kan gøres til genstand for forskning som enhver anden genstand, mente de tidlige sociologer.

Men denne genstand har efter 100 års sociologi vist sig at være alt andet end et stykke mekanik, der upåvirket af os afventer vores beskrivelser og teoretiseren. Den sociale virkelighed erkendes nu som en proces, der kaster strukturer af sig (Marx 1963; Elias 1997). Samfundet skabes løbende, det konstrueres (Schütz 1967; Berger \& Luckmann 1966). Menneskers sociale liv er ikke lovbestemt eller determineret, men emergent (Mead 1934; Stacey 2001). Og så videre. En simpel, mekanisk realisme kan ikke længere forsvares samfundsvidenskabeligt. Dermed svinder også grundlaget for at opfatte en teori som en afbildning af en ydre (statisk) virkelighed.

Men derfor kan forskerne jo godt stille sig lidt uden for denne foranderlige virkelig- hed og formulere teorier om den? Bestemt, jo. Det er ikke svært, hvad angår fysiske og biologiske fænomener, for her forløber evolutionen ikke så hurtigt, at molekylers eller geners essentielle kendetegn forandres i en forskers levetid. Men med menneskers psykosociale virkelighed går det stærkt. Den kan som bekendt ændre sig radikalt på få år eller ligefrem uger - tænk på de problemer, økonomerne har med at begribe den internationale finanskrise i 2008 ud fra etablerede videnskabelige teorier. Hvis det kan gå så stærkt, hvorfor skulle en passende teori så være statisk og foregive at være sand i betydningen 'et billede af tingenes nuværende tilstand'? Hvordan kan sådan en teori være andet et snapshot af i går?

Lad os spørge omvendt: Hvorfor skulle bevægelsen fremad, mod nye fremtider, handlemåder og samfundsinstitutioner, ikke tages med i betragtning af forskerne? Lad os indoptage fremtiden i human- og samfundsvidenskaberne. Ikke forstået som noget der kan forudsiges, for det ville jo blot være den klassiske videnskabs determinisme. Humane fænomener er ikke forudbestemte, mennesker har frihed, vi prøver at vælge, og vi vejledes af værdier, forestillinger om hvad der er godt, godt for en selv og så mange andre, som man nu kan har kræfter til at tænke med.

Evolutionært, bl.a. drevet af overlevelsestrang (Pinker 2002) og en almen biologisk tendens til ordensdannelse (Goodwin 1994), er vi skabt med denne trang til at gøre hver enkelt lille hverdagshandling så godt, som vores ressourcer tillader, og vores værdier tilsiger samt skabe orden i vores hjørne af virkeligheden: vi prøver at skaffe så god en føde, vi kan, forhandle en ansættelseskontrakt vi selv opfatter som god, føre den rigtige udenrigspolitik som hver regering nu forstår dét.

En passende type forskning kunne således udmærket forsøge at kvalificere disse nye fremtider, der bryder frem altid allerede. 
Tænker vi pragmatisk, humanistisk, evolutionspsykologisk og socialkonstruktionistisk er det ikke svært at konkludere, at i hvert fald en del af den human- og samfundsvidenskabelige indsats må rettes mod at nykonceptualisere og medskabe menneskers fremtidige institutioner og udfoldelsesmuligheder.

En sådan begrebssættelse af en anderledes og bedre organisering af menneskers aktivitet (husk eksemplet: møder der skaber værdi og mening, fordi de faciliteres) kan vi kalde en teori - der ikke er historisk og forklarer, hvorfor fænomenet er opstået (som fx vores identifikation af de autoritære og egalitære træk i dansk mødehistorie), men er fremtidsrettet og transformativ, fordi den peger i retning af, hvad vi skal gøre for at bryde det historiske mønster og komme nye og forhåbentlig bedre steder hen.

En transformativ teori kan vi kalde videnskabelig i den udstrækning, den besidder følgende to klassisk videnskabelige træk:

1. Teorien er vidensbaseret. Teorien er funderet i den bedste tilgængelige, forskningsbaserede viden om menneskers biologiske og psykologiske potentialer og sociale og politiske muligheder på det relevante område. In casu, viden om møder, facilitering, teamarbejde, gruppeprocesser og videndeling skal lægges til grund for teorien, der således tilstræbes at være dybdereflekteret, logisk sammenhængende og åben for offentlig drøftelse og prøvelse. Teorien er ikke en travl konsulents hurtige koncept, og den er ikke udledt af en ideologi, formet af skjulte særinteresser eller håndhævet af et politisk parti.

2. Teorien er testbar. Teoriens påståede gyldighed kan afprøves. Der kan formuleres distinkte og testbare hypoteser fra teorien. Den er ikke holistisk i betydningen analytisk urørlig; den skal ikke tages for pålydende, den skal ikke holdes fri af vanhelligelse, den hidrører ikke fra religi- øse dogmer hinsides kritik og tvivl. Teorien skal kunne operationaliseres, således at praktiske eksperimenter afprøver den i sin helhed eller dele af den, og den skal revideres og forbedres i lyset af denne praktiske afprøvning.

Taler vi om en teori som en beskrivelse af en god fremtidig tilstand for mennesker på et bestemt område (i eksemplet: et godt møde), tårner der sig et kors for tanken op foran os: Fint, fremsæt en teori om hvad der udgør gode møder; men hvem skal afgøre, hvad der er godt i møder?

Et simpelt demokratisk svar er, at det skal de mennesker, der lever på det pågældende område, dvs. de mennesker hvis liv påvirkes af områdets institutioner og normer (Ackoff 1984). Invitér de mennesker med i et eksperiment, hvor vi afprøver teorien, og hør hvad de siger bagefter. Underkast deres svar kritisk afprøvning og refleksion - mener de virkelig, hvad de siger? Udfordr dem til at tænke sig ordentligt om og mærke ordentligt efter; acceptér ikke uigennemtænkte eller skødesløst afgivne vurderinger.

Men før vi kan designe et eksperiment til afprøvning af en teori, skal vi på baggrund af teorien formulere nogle hypoteser, der fortæller os, hvad vi skal gøre konkret. Det er næste trin:

\section{Formulering af hypoteser, dvs. handlingsanvisninger}

Klassisk tjener hypoteser jo til at afprøve, hvor godt en teori stemmer overens med virkeligheden i en konkret situation. Men transformativt søger vi ikke at forstå menneskers virkelighed, som den 'er'; vi søger at forbedre den. En hypotese er derfor en teoriafledt formodning om, at når vi udfører handling X i en konkret situation $\mathrm{Y}$, så vil vi nærme os dén bedre tilstand, som teorien beskriver. 
Vi kan da bruge ordet hypotese således:

"Jeg har en hypotese om, at hvis vi til ledergruppemødet (situation Y) beder HR-chefen facilitere og involvere mødedeltagerne ved brug af bestemte teknikker (handling X), så direktøren ikke bruger meget af taletiden, som han plejer, så får vi et møde, der skaber mere mening for de deltagende ledere og mere voerdi for virksomhedens kunder."

En hypotese peger således på en praktisk handling, der formodes at ville bidrage til en bedre fremtid. Hypotesen er ikke, som i klassisk forskning, en påstand om, at en bestemt nutidig tilstand eller årsagssammenhæng forefindes.

Ovenfor omtalte jeg vores tre overordnede forventninger til projekt MSVM som 'hypoteser' om, hvordan variablerne Mødeledelse, Facilitering, Mening og Værdi ville score. De to første deskriptive rettede sig til vores førmåling: vi forventer, at lederne scorer højt på mødeledelse og lavt på facilitering, og at møderne scorer lavt på mening og værdi. Kun den tredje hypotese er transformativ: Ved at træne lederne i facilitering forventer vi, at de begynder at facilitere deres møder (i stedet for blot at lede dem klassisk), og at disse møder derfor skaber mere mening for deltagerne og værdi for mødets eksterne interessenter (jf. Elsborg \& Ravn 2006, 14).

Det særlige i transformativ metode er således, at hypoteser er handlingsanvisninger, der har til formål at ændre virkeligheden, ikke blot fortolke den anderledes (jf. Marx' 11. tese om Feuerbach).

\section{Eksperiment: Teorien afprøves på praksisfeltet}

Human-sociale eksperimenter kan af velkendte grunde ikke kan leve op til de klassiske naturvidenskabelige krav om variabelkontrol, men mindre kan også gøre det. I det transformative eksperiment testes de teori-afledede hypoteser eller handlingsanvisninger af nogle af de mennesker, der lever og arbejder på det relevante felt. Disse mennesker ændrer deres daglige praksis eller indfører nye institutioner som specificeret af handlingsanvisningerne, og efter en periode vurderer deltagerne og forskerne sammen, om disse ændringer førte deltagerne tættere på målet.

I trafiksikkerhedsforskning foretages eksperimenter, vi udmærket kan kalde transformative. Et tænkt eksempel: I fem villakvarterer installeres diverse fysiske fartbegrænsninger, og efter tre år ser vi, hvordan det går med ulykkesstatistikken. Bag dette ligger der naturligvis en slags transformativ teori: Det gode villakvarter er indrettet, så bilisterne kører forsigtigt. Vores forskere formulerer et par hypoteser, der anviser, hvad der skal installeres. Hypotese 1: Blinkende lysbump. Hypotese 2: Kørebaneindsnævring med bænke. Hypotese 3: Begge dele.

Forskerne rekrutterer et par kommuner, der får nogle grundejerforeningers velsignelse, forhindringerne etableres, gennemsnitshastigheder og ulykker måles, beboere interviewes, og forskerne skriver resultaterne sammen: Bumpene nedbragte hastigheden med $4 \mathrm{~km} / \mathrm{t}$, men kun hvis der også var bænke; der var kun to små ulykker færre over de tre år, men beboerne var tilfredse og trafikanterne også. Hvad lærte vi? Fx: "Tentativ bekraeftelse af hypoteserne. Lad os afprøve dem $i$ et større eksperiment, før vi anbefaler dem i hele landet."

Sådan tænker trafikforskere transformativt, uden at det giver videnskabsteoretiske problemer. Ingen trafikforskere vil påstå, at det er lykkedes dem at fastslå det ultimativt gode nærtrafikmiljø, og selvfølgelig har forskellige borgere og politikere forskellige holdninger til, hvordan trafikforhold skal være. Men forskerne har prøvet sig frem i et videnskabeligt eksperiment og er parat til 
at blive klogere, hvis andre har evidens for andre konklusioner.

Lad os se på projekt MSVM; hvad var eksperimentet dér? Det skulle naturligvis udgøres af møder, der faciliteres, for kun derigennem kunne vi vurdere, om facilitering ville skabe mening og værdi på møder. Men hvem skulle stå for denne facilitering? Hyrede vi uafhængige facilitatorer, ville vi teste deres evner og næppe opnå en varig forbedring $\mathrm{i}$ virksomhederne, efter facilitatorerne sagde farvel. Vi skulle have virksomhedernes egne mødeledere på banen, så de skulle trænes i facilitering først (hvilket vi selv tog os af).

Denne træning introducerede en ekstra usikkerhed, fordi det ikke blot er lederens facilitering, som den efterfølgende evaluering måler, men også vores evne til at undervise dem i facilitering og motivere dem for det. Denne ulempe overvejedes dog af den varige kompetenceudvikling, som vi antog træningsforløbet bidrag med - og som, ikke at forglemme, var en primær årsag til, at virksomhederne valgte at deltage i projektet og betale for det.

Vi trænede lederne kollektivt (workshops) og individuelt (coaching), og vi bistod hver virksomhed med at finde en ny struktur for to almindelige mødetyper (bl.a. kontormødet, ledergruppemødet og projektmødet). Under dette træningsforløb afviklede mødelederne naturligvis deres daglige møder. Eksperimentet var således: Ville denne daglige mødeledelse ændres i løbet af træningsperioden?

\section{Måling: Fungerede handlingsanvisningerne?}

Vi gennemførte en eftermåling gennem mødeobservationer, interview med ledere og medarbejdere samt spørgeskemaundersøgelse af mødedeltagerne. Den blev sammenlignet med førmålingen for at konstatere en evt. effekt.
I en sådan måling råder de sædvanlige udfordringer med intern validitet, som også interventionsforskning og den forskningsbaserede evaluering af forandringsprojekter kæmper med. Én faktor sprang dog i øjnene i MSVM, og det er vores personlige medvirken som faciliteringstrænere og møderedesignere. At vi med MSVM gerne ville kunne vise, at facilitering er et godt møderedskab, og at vi sideløbende med forskningen yder universitetsbaserede konsulentydelser baseret på facilitering af møder, får os naturligvis til afvente eftermålingens resultater med særlig spænding. Men det gælder jo for de fleste forskere, at egen stolthed og levebrød hænger intimt sammen med ens forskningsprojekters udfald. Dette forhold fordrer selvrefleksion og integritet, men rokker ikke principielt ved videnskabeligheden.

\section{Andring af teori}

Når en stor virksomhed evaluerer en intern forandringsindsats, går de projektansvarlige somme tider direkte fra måling til anbefaling: "Her i de otte forsøgsafdelinger gik det rigtig godt med den nye teamstruktur, så lad os indføre den i vores 80 andre afdelinger!".

Men $v i$ taler om en forskningsindsats, og derfor kræver det mere omtanke, og det er den fra klassisk forskningsmetode så velkendte fase: ændring af teori. Hvad lærte vi af målingerne, blev hypoteserne bekræftet eller svækket, og hvad siger dét om teorien bag, altså vores forestilling om, hvad der udgør et godt møde? Var teorien realistisk, syntes den relevant for mødelederne og -deltagerne, udtrykte den deres behov, blev alles interesser tilgodeset, inspirerede den dem til handling, pegede den på væsentlige indsatsområder? Hvis ikke, hvordan kan teorien så forbedres, så den bedre kan guide os eller andre i et senere eksperiment?

Når andre forskere undersøger og kritiserer den viden, vi mener at have skabt $\mathrm{i}$ 
det transformative eksperiment, kan videnskabelige fremskridt finde sted. Der er ingen garanti for, at vi nogensinde forbedrer møder for ret mange - endsige alle - mennesker, men det er jo håbet, at vi med stadig flere eksperimenter og praksiserfaringer kan forfine vores forståelse af møder, så vi også bliver i stand til at tilrettelægge og afvikle mange slags møder i mange kulturer bedre og bedre. Hermed har vi taget fat på sidste fase:

\section{Generalisering - til kvalificering af praksis}

Når vi skal uddrage en lære af det transformative eksperiment, har vi de velkendte spørgsmål om ekstern validitet, som optager enhver evalueringsforsker: Hvad var de særlige betingelser her, og hvad kan tænkes at virke andre steder? Hvem foretog evalueringen, hvem har magten til at tale og handle på projektet og dets erfaringer, og er det dem, der betalte, der fortæller historien om forsøget?

At vi i transformativ forskning har med en eksplicit og teoretisk funderet normativ indsats at gøre, skærper kun kravene til forskernes hæderlighed, videnskabelige analyse og sobre præsentation af resultaterne. Men det rykker ikke ved principperne for generalisering, som de kendes fra interventionsforskning og projektevalueringer alment.

\section{Faserne i transformativ metode}

Lad os sammenfatte de nævnte faser i en transformativ forskningscyklus:

a. Et initialt praktisk problem udfordrer os til at formulere en

b. vidensbaseret normativ teori for, hvordan praksisfeltet kunne se ud i en stærkt forbedret udgave. Fra den teori afleder vi passende c. handlingsanvisende og testbare hypoteser, der afprøves i et

d. praktisk, reelt eksperiment med deltagere fra det pågældende felt. Ved hjælp af en

e. måling eller evaluering søger praktikerne og forskerne at vurdere, om praksis blev forbedret. Her ud fra foretager vi en

f. modifikation af teorien. En endelig

g. generalisering hjælper os med at anvende det lærte andre steder.

\section{Konklusion: En forskningsmetode der bidrager mere}

Jeg har skitseret nogle trin i en forskningsmetode, der involverer forskere $i$ at bidrage til udvikling af det felt, de undersøger. På den ene side ser denne metode velkendt ud, for er det ikke bare interventionsforskning med andre ord, eller er det ikke bare evaluering af et socialt eksperiment? På den anden side beder jeg læseren sluge nogle gevaldige kameler, hvad angår værdier og facts: Som forskere skal vi selv til at opstille idealer for de institutioner og praksisfelter, vi undersøger. Bedriver vi ikke lige interventionsforskning, plejer vi at lade praktikere og politikere om denne lidt rodede side af sagen. Når indsatsen har kørt et par år, kaldes vi ind for at evaluere den, og vi kan på metodisk tryg afstand løfte vores kritiske pegefingre.

Men spørgsmålet er, om det ikke er alt for beskeden og steril en rolle for forskerne at indtage. Hvorfor skal den meget store viden, som mange forskere opbygger gennem årtiers studier af et praksisfelt, ikke mere direkte komme feltets praktikere til gode? En typisk erfaren forsker vil have masser af ideer og forestillinger om, hvad der vil virke godt på feltet. Lige nu spiller de ingen rolle i hendes forskning, de må ikke spille nogen rolle, for så politiserer hun. I interviews og som rådgiver for praktikere kan hun præsentere de smuler, der nu er plads til dér, men samlet og systematisk har en forsker sjældent lej- 
lighed til at bruge sin viden om, hvordan tingene kunne fungere bedre - med mindre man altså befinder sig i en af de få og små lommer i samfundsforskningen, hvor der er tradition for interventionsforskning.

Ved anvendelse af metode som den transformative inviteres forskeren til at bruge sin viden om menneskelige og sociale potentialer aktivt. Her bidrager hun til den intellektuelt krævende proces at formulere en transformativ eller normativ teori for området. Hun bidrager - som interventionsforskere allerede gør - med videnskabens omfattende erfaringer med eksperimentelt design, og hun bidrager - ligesom evalueringsforskere - med viden om resultatmåling og generalisering.

Det centrale nye, jeg har argumenteret for i denne artikel, er teoridelen: forestillingen om at teori, dette væsentlige element $i$ al videnskab, i en transformativt orienteret samfundsforskning kan handle om dén bedre tingenes tilstand, som forskere, gerne i samkvem med praktikere, kan forsøge at formulere for det pågældende praksisfelt. I en social verden, der stadig forandres og konstrueres, og hvor aktører handler og forhandler i forsøget på at skabe deres foretrukne virkeligheder, synes det oplagt, at samfundsforskere skal bidrage med fornuftige, sammenhængende og vidensbaserede billeder på ønskværdige fremtider for alle deltagere i et praksisfelt, billeder der skal testes videnskabeligt og eksperimentelt, så vi bliver klogere på, hvad der fungerer, og kan bidrage til at forbedre menneskers udfoldelsesmuligheder og handlinger.

At forskere skal give sig af med at formulere idealforestillinger om praksisfelter vil muligvis virke frastødende på både forskere, lægmand og samfundets beslutningstagere. Men det er kun, hvis man tænker positivistisk - eller rettere: ontologisk realistisk om sådanne teorier, altså hvis man mener, at de pågældende forskere foregiver at være i stand til at fastslå en idealforestillings endelige sandhed som en slags overensstemmelse med en ydre objektiv virkelighed. Pragmatisk og konstruktionistisk er forskere langt hinsides denne opfattelse af, hvad teori er. En teori er en foreløbig og hyppigt mangelfuld forståelse, der skal testes og kritiseres fortløbende og således hele tiden kan blive bedre, evt. fremstå som en af mange teorier på det videnskabelige marked.

På sigt vil samfundet utvivlsomt have gavn af en større transformativ interesse $i$ samfundsforskningen. Arbejdslivsforskningen kan gerne tjene som eksempel på et felt, der har gode erfaringer med, at normativt interesserede forskere gennem interventioner eksperimenterer med socialtorganisatoriske forbedringer. Forsøg, der ikke giver klare resultater, som den seneste store satsning på psykisk arbejdsmiljø gennemført af landets førende forskere på feltet (Hasle m.fl. 2008), er at forvente. Langt fra alt lykkes, når man eksperimenterer. Sådan et udfald er småting i forhold til arbejdsmiljøforskningens enorme indsats de sidste par årtier for dét bedre arbejdsliv på danske arbejdspladser, som andre lande misunder os.

I en række nicher anstiller danske forskere eksperimenter, der er teoribaserede - inden for bl.a. arbejdsmiljø, trafiksikkerhed, kriminalprævention (Balvig m.fl. 2005) og negativ social arv (Jensen m.fl. 2009). Men antropologer, psykologer, sociologer, økonomer og politologer kunne i langt højere grad berige samfundet med konkrete udviklingsindsatser, der for alvor ville stille forskerens betydelige intellektuelle ressourcer til rådighed for resten af befolkningen.

Som jeg har fremført i denne artikel, er én forudsætning herfor måske, at vi nyfortolker teoribegrebet i samfundsforskningen, så det det kommer op på niveau med den aktuelle, udbredte opfattelse af social virkelighed som dynamisk, konstrueret og under stadig forhandling mellem parter, 
der alle har deres bud på nye virkeligheder og fremtider. Hvis mennesker hver time på dagen konstruerer virkeligheder for fuld skrue, hvorfor skal forskere så lade som om, de ikke gør det? Hvorfor skal de ikke bidrage efter bedste evne til konstruktionen af nye og bedre virkeligheder (Ravn 1991)? Vi har brug for en forståelse af den human-socialvidenskabelige indsats, der tillader forskere qua forskere at bidrage mere konstruktivt og offensivt til udviklingen af sociale praksisser og organisatoriske processer.

\section{REFERENCER}

Ackoff, Russell L. (1981): Creating the Corporate Future, New York, Wiley.

Ackoff, Russell L. (1994): The Democratic Corporation, Oxford University Press.

Baburoglu, Oguz, \& Ib Ravn (1992): Normative Action Research, i Organization Studies, 13, 1, 19-35.

Balvig, Flemming, Lars Holmberg \& Anne-Stina Sørensen (2005): Ringstedforsøget - livsstil og forebyggelse i lokalsamfundet, Jurist- og Økonomforbundets Forlag.

Berger, Peter, \& Thomas Luckmann (1966): The Social Construction of Reality, New York, Doubleday.

Bjerre, Poul (1972): Videnskabens natur, København, Gyldendal.

Bjerre, Poul (1988): Opbrud. Utopisk humanisme, København, Gyldendal.

Blegvad, M. (1959): Den naturalistiske fejlslutning. København, Gyldendal.

Brinkmann, Svend (2009): Facts, Values, and the Naturalistic Fallacy in Psychology, i New Ideas in Psychology, 27, 1, 1-17.

Cobb, Paul, m.fl. (2003): Design Experiments in Educational Research, i Educational Researcher, 32, 1, 9-13.

Deci, Edward L., James P. Connell \& Richard M. Ryan (1989): Self-Determination in a Work Organization, i Journal of Applied Psychology, 74, 580-590.

Dewey, John (1929): Experience and Nature, London, Allen Unwin.

Donaldson, T., \& L.E. Preston (1995): The Stakeholder Theory of the Corporation, i Academy of Management Review, 20, 65-91.

Elias, Norbert (1997): Towards a Theory of Social Processes: A Translation, i British Journal of Sociology, 48, 355-83.

Elsborg, Steen \& Ib Ravn (2006): Laerende møder og konferencer i praksis, People's Press.

Friedman, Victor J. \& Ariane Berthoin Antal (2005): Negotiating Reality: A Theory of Action Approach to Intercultural Competence, i Management Learning, 36, 69-76.

Gergen, K. J. (1982): Toward Transformation in Social Knowledge, New York, Springer-Verlag.

Ghoshal, Sumantra, Christopher A. Barlett \& Peter Moran (1999): A New Manifesto for Management, i Sloan Management Review, 40, 3, 9-20.

Gimmler, Antje (2003): Pragmatisk sociologi - 'det bedste er endnu i vente', i Michael Hviid Jacobsen (red.): Sociologiske visioner, Systime Academic.

Goodwin, Brian C. (1994): How the Leopard Changed its Spots: The Evolution of Complexity, London, Weidenfeld and Nicolson.

Hasle, Peter m.fl. (2008): Virksomheders indsats for et bedre psykisk arbejdsmiljø, København, NFA.

Hogan, Christine (2003): Understanding Facilitation: Theory and Principles, London, Kogan Page.

Hume, David (1741/1986): A Treatise of Human Nature. Ernest Campbell Mossner (red.), London, Penguin.

Isaksen, Jesper (2000): Constructing Meaning Despite the Drudgery of Repetitive Work, Journal of Humanistic Psychology, 40, 84-107. James, William (1907): Pragmatism, New York, Longmans, Green and Co.

Jelenik, Mariann, A. Georges Romme \& Richard J. Boland (2008): Introduction to the Special Issue: Organization Studies as a Science for 
Design, i Organization Studies, 29, 3, 317-329.

Jensen, Bente, m.fl. (2009): Effekter af indsatser for socialt udsatte børn i daginstitutioner, København, Danmarks Pædagogiske Universitetsforlag.

Kristensen, Tage Søndergaard (2005): Intervention Studies in Occupational Epidemiology, Occupational and Environmental Medicine, 62, 205-210.

Marx, Karl (1963): Selected Writings in Sociology and Social Philosophy, Tom B. Bottomore \& Maximilien Rubel (red.), 2.edn, Harmondsworth, U.K., Penguin.

Maslow, Abraham H. (red.) (1959): New Knowledge in Human Values, New York, Harper and Row.

Mead, George Herbert (1934): Mind, Self and Society, Chicago, Ill., Chicago University Press.

Meyer, Niels I., K. Helveg Petersen \& Villy Sørensen (1978): Oprør fra midten, København, Gyldendal.

Moore, G. E. (1903): Principia Ethica, Cambridge, Cambridge University Press.

Pinker, Steven (2002): The Blank Slate, New York, Viking.

Ravn, Ib (1985): Creating Futures, Constructing Realities, i General Systems Yearbook, 29, 7-15.

Ravn, Ib (1991): What Should Guide Reality Construction?, i Frederick Steier (red.): Research and Reflexivity, 96-116, London, Sage.

Ravn, Ib (2007): Meetings in Organizations: Do they Contribute to Stakeholder Value and Personal Meaning?, Paper presented to the Academy of Management, Philadelphia, USA, August 6-8.

Ravn, Ib (2008): Mening i arbejdslivet - definition og konceptualisering, i Tidsskrift for
Arbejdsliv, 10, 4, 59-75.

Reason, Peter \& Hilary Bradbury (red.) (2001): Handbook of Action Research, London, Sage. Richards, Janet Radcliffe (1981): HypotheticoDeductive Method, i W.F. Bynum, E.J. Browne \& Roy Porter (red.): Dictionary of the History of Science, s. 196, Princeton, N.J., Princeton University Press.

Romano, N. \& J.F. Nunamaker (2001): Meeting Analysis: Findings from Research and Practice, i Proceedings of the 34th Hawaii International Conference on Systems Sciences, Hawaii, USA.

Rothman, J. \& E.J. Thomas (red.) (1994): Intervention Research: Design and Development for Human Service, New York, The Haworth Press.

Schütz, Alfred (1967): The Phenomenology of the Social World, Evanston, IL, Northwestern University Press.

Schwartzman, H. B. (1986): The meeting as a neglected social form in organizational studies, i Research in Organizational Behavior, 8, 233-258.

Searle, J. (1964): How to derive 'ought' from 'is', i Philosophical Review, 73, 54-71.

Stacey, Ralph D. (2001): Complex Responsive Processes in Organizations, London, Routledge.

Sørensen, Villy (1973): Samfundsvidenskab og målsætning, i Uden mål - og med. Moralske tanker, 133-161, København, Gyldendal.

van Aken, J. E. (2005): Management Research as a Design Science, i British Journal of Management, 16, 19-36.

Weick, Karl (1995): Sensemaking in Organizations, London, Sage.

Ib Ravn, ph.d., er lektor ved Institut for Læring, Danmarks Pædagogiske Universitetsskole, Aarhus Universitet.

e-mail: ravn@dpu.dk 